Original Research Article

\title{
Spectrum of opportunistic infections in HIV infected children in North India
}

\author{
Pandey C.M ${ }^{1}$, Shrivastava $A^{2}$ \\ ${ }^{1}$ Dr. Chandra Mani Pandey, Consultant, ${ }^{2}$ Dr. Anubha Shrivastava, Assistant Professor; both authors are affiliated with \\ Department of Paediatrics MLN Medical College, Allahabad, UP, India.
}

Address for Correspondence: Dr. Chandra Mani Pandey, Consultant Paediatrician, 31/13, Church Lane, Allahabad, UP. Email- pandeycm@rediffmail.com

\begin{abstract}
Introduction: Human Immunodeficiency Virus adversely affects the immune system of the body, making a person vulnerable to variety of infections. Usually benign micro organisms become virulent and cause serious illnesses. Such opportunistic infections are very common in HIV infected children. If they are not diagnosed and treated in time they may prove fatal. The pattern of opportunistic infections are changing with time and place. To study the newer pattern of opportunistic infection in HIV infected children, this study was undertaken. Methods: 140 children of both sexes between age 18 months to 15 years, diagnosed HIV positive as per NACO HIV testing guidelines, were included in this study. They were examined, investigated and classified into clinical and immunological staging as per WHO classification. They were investigated for opportunistic infections. Result: Different kinds of skin involvement including scabies, papular pruritic eruptions, seborrhoic dermatitis, pyoderma, herpes zoster, molluscum contagiosum, fungal infections were noted in $47 \%$ children. Oropharyngeal candidiasis was also common. Recurrent respiratory tract infection, recurrent diarrhea, urinary tract infection, CSOM, parotid involvement was seen in majority of children. Over all, bacterial infection was seen in $36.4 \%$ children, followed by fungal infection in $18.5 \%$, viral infection in $14.3 \%$ and tubercular infection in $10 \%$ respectively. Several studies have reported tuberculosis as the most common opportunistic infection in HIV infected children, but contrary to this, tuberculosis was the fourth commonest opportunistic infection in our study. Recurrent bacterial infections were the commonest one. Pneumocystis Carinii Pneumonia (PCP), the hallmark of AIDS defining illness in developed world, is not so common in our set up. We found only one probable case of PCP in our study.
\end{abstract}

Key words: Children, HIV infection, Opportunistic infections

\section{Introduction}

HIV infection adversely affects the human immune system and making a person susceptible for micro organisms to cause disease. Usually benign microbes become virulent and cause serious illnesses. Children are easy victims of these opportunistic infections (OI), disease progression is faster and they usually die of these conditions if not diagnosed and treated in time. In our set up diagnosis is mostly based on clinical signs

Manuscript received: $17^{\text {th }}$ September 2016

Reviewed: $28^{\text {th }}$ September 2016

Author Corrected; $11^{\text {th }}$ October 2016

Accepted for Publication: $22^{\text {nd }}$ October 2016 and symptoms and picked up when disease is quite advanced. Spectrum of these infections is changing with time and place. Pneumocystis Carinii, once upon a time said to be the hall mark of HIV infection [1], is not so common in these children [2,3]. Various studies have shown that pulmonary tuberculosis [4-6] and extra pulmonary tuberculosis [7] had been the most common opportunistic infection in our country but in children this trend is changing. Various types of cutaneous manifestations can occur in up to $90 \%$ of HIV infected individuals [8]. Scabies and dermatophytes are common conditions in our country [9]. 
Oral candidiasis is seen in $70 \%$ of cases [6]. Change in pattern of opportunistic infections may be due to various factors including individual susceptibility, prevalence of particular organism in that area, ecological factors and increasing availability and use of anti retro viral drugs. To study the emerging pattern of newer opportunistic infections, this study was planned.

\section{Methods}

This observational study was conducted at S. N. Children Hospital, department of Paediatrics, M. L. N. Medical College Allahabad and A. R. T. Centre of S. R. N. Hospital Allahabad, U.P. during the period April, 2005 - October, 2012.140 children of both sexes between the ages 18 months to 15 years, who were newly diagnosed HIV positive as per National AIDS Control Organization HIV testing guide lines were included in this study. Previously diagnosed HIV positive children were not included in this study. Children less than 18 months were also excluded due to limitations of diagnostic facilities. These children were selected from ART Center SRN Hospital Allahabad and SN Children Hospital Allahabad, UP. Care takers were counseled by qualified counselors and written consent was taken to examine and investigate. Data was recorded on pre structured proforma.

Anthropometric measurements, general and systemic examinations, complete blood count and CD4 counts were done in all cases. Other relevant investigations to diagnose opportunistic infections were done where ever required. Clinical and Immunological staging was done as per WHO staging criteria. CD4 count was done with Partec CyFlow ${ }^{\circledR}$ counter flow cytometer. Method- Venous blood sample was collected in a tube containing EDTA solution. 20micro L whole blood from EDTA tube was added to Partec test tube. 20microL of CD4 buffer (m Ab PE) was added to it. It was mixed gently and incubated for 15 minutes at room temperature and protected from light. Now 800microL of no lyse buffer was added and shaken gently. This 840 microL prepared blood was transferred to Partec Flow Cytometer and CD4 count was carried out. CD4 count and CD4\% were used to assess the immunological staging. Percentage of CD4 cells were calculated on the basis of absolute CD4 count by using following formula-

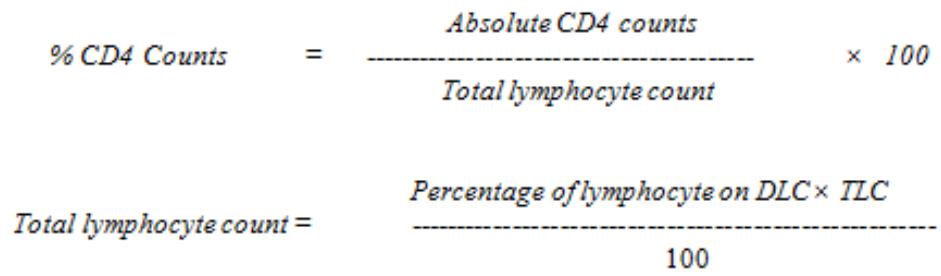

Statistical analysis: To describe nominal data, simple percentages were used. Mean and Standard Deviations were used to describe normally distributed data.

\section{Results}

Out of 140 children, 91 were male and 49 were female with male to female ratio 1.86:1. Maximum numbers of children, (61) were in between age group 5-10 years. Mean age of presentation was 7.67 (SD \pm 3.5 ) years which ranged from 18 months to 15 years. $75.71 \%$ were from rural back ground. 10 (7.14\%) children lost their both parents while 37 (26.43\%) children lost either father or mother. Total 47 (33.57\%) children were orphan. According to IAP nutritional classification, $101(72.14 \%)$ children were significantly undernourished and $39(27.86 \%)$ children were in mild grade of under nutrition. No child was nutritionally normal.

Majority of children, $101(72.14 \%)$ were in Socio Economic Status III \& IV of B .G. Prasad's classification. 137 $(97.86 \%)$ children were infected perinatally, two $(1.43 \%)$ through blood transfusion and in one $(0.71 \%)$ case mode of infection could not be ascertained. On the basis of clinical staging, $115(82.14 \%)$ children were in clinical stage II and III, $17(12.14 \%)$ in stage I and eight (5.72\%) in stage IV. According to immunological staging, 50 (35.72\%) children were in stage I, 27 (19.28\%) in stage II, $38(27.15 \%)$ in stage III and $25(17.85 \%)$ in stage IV. 47.14\% children had various types of skin lesions as shown in 
Table.1. Age wise distribution of opportunistic conditions in Table. 2 shows that recurrent diarrhoea, recurrent respiratory infections, otitis media, tuberculosis, recurrent urinary tract infections and oropharyngeal candidiasis are common. In $31(22.14 \%)$ children more than one condition was present. Table.3 shows opportunistic organisms in relation to clinical and immunological staging. Organism wise details of UTI and Persistent diarrhoea cases are shown in Table.4 and 5 respectively. Central Nervous System involvement was seen in six (4.28\%) children, bacterial meningitis in three, tubercular meningitis, cryptococcal meningitis and encephalopathy one each. By the end of this study six children lost their lives, three due to C.N.S. complications, one bacterial pneumonia, one milliary tuberculosis and one due to Non Hodgkin's Lymphoma.

Table-1: Type of skin lesions of patients in the present study (N-66)

\begin{tabular}{|c|c|c|}
\hline Type of skin lesions & Number & Percentag \\
\hline Scabies & 13 & 09.28 \\
\hline Papular Purpuric Erruptions & 13 & 09.28 \\
\hline Pyoderma & 12 & 08.57 \\
\hline Seborrhoic dermatitis & 07 & 05.00 \\
\hline Fungal skin infection & 05 & 03.57 \\
\hline Fungal nail infection & 03 & 02.12 \\
\hline Chicken pox & 04 & 02.85 \\
\hline Herpese zoster & 02 & 01.42 \\
\hline Cheloid & 02 & 01.42 \\
\hline Non-healing ulcer & 02 & 01.42 \\
\hline Molluscum contagiosum & 03 & 02.14 \\
\hline
\end{tabular}

Table 2: Age wise distribution of opportunistic conditions

\begin{tabular}{|c|c|c|c|c|}
\hline Opportunistic conditions & 1.5- 05 years & 05- 10 & 10- 15 & Total \\
\hline Tuberculosis & 02 & 05 & 07 & 14 \\
\hline Rec. Bact. pneumonia & 01 & 10 & 02 & 13 \\
\hline Rec. Empyema thorasis & 00 & 03 & 00 & 03 \\
\hline Rec. Diarrhoea & 06 & 15 & 05 & 26 \\
\hline Skin conditions & 14 & 24 & 28 & 66 \\
\hline Oropharyngeal candidiasis & 06 & 02 & 02 & 10 \\
\hline Rec.UTI & 04 & 03 & 03 & 10 \\
\hline Rec. Pyogenic meningitis & 02 & 00 & 01 & 03 \\
\hline CSOM & 06 & 04 & 07 & 17 \\
\hline Systemic.Viral infection & 02 & 03 & 02 & 07 \\
\hline Cryptococcal meningitis & 00 & 00 & 01 & 01 \\
\hline Pneumocystis carinii pneumonia & 00 & 00 & 01 & 01 \\
\hline HIV Encephalopathy & 00 & 00 & 01 & 01 \\
\hline Non Hodgekins Lymphoma & 01 & 00 & 00 & 01 \\
\hline
\end{tabular}


Table-3: Nature of opportunistic organisms in relation to who clinical and immunological staging

\begin{tabular}{|c|c|c|c|c|}
\hline $\begin{array}{c}\text { WHO Clinical and } \\
\text { Immunological staging }\end{array}$ & Tubercular & Pyogenic & Fungal & Viral \\
\hline Clinical stage I & 00 & 02 & 00 & 01 \\
\hline Immunological stage I & 00 & 14 & 11 & 12 \\
\hline Clinical stage II & 01 & 21 & 03 & 05 \\
\hline Immunological stageII & 01 & 08 & 13 & 06 \\
\hline Clinical stage III & 10 & 24 & 11 & 01 \\
\hline Immuno.stage III & 08 & 17 & 04 & 03 \\
\hline Clinical stage IV & 03 & 03 & 10 & 20 \\
\hline Immuno. Stage IV & 05 & 12 & 26 & 02 \\
\hline Total & 14 & 51 & & 06 \\
\hline
\end{tabular}

Table -4: UTI cases according age \& sex

\begin{tabular}{|c|c|c|c|c|c|c|}
\hline \multirow[t]{2}{*}{ UTI organism } & \multicolumn{3}{|c|}{$\begin{array}{c}\text { Age \& sex } \\
01.5-05 \text { yr }(n-41)\end{array}$} & \multicolumn{3}{|c|}{$\begin{array}{c}\text { Age \& sex } \\
05-15 \text { yr (n-99) }\end{array}$} \\
\hline & $\mathbf{F}$ & $\mathbf{M}$ & T\% & $\mathbf{F}$ & $\mathbf{M}$ & T\% \\
\hline E. Coli & 1 & 1 & $2(4.88)$ & 1 & 2 & $3(3.03)$ \\
\hline Kleibsella & 0 & 1 & $1(2.44)$ & 0 & 2 & $2(2.02)$ \\
\hline St . aureus & 0 & 1 & $1(2.44)$ & 0 & 0 & 0 \\
\hline Trichomonas & 0 & 0 & 0 & 1 & 0 & $1(1.01)$ \\
\hline Total & 1 & 3 & $4(9.76)$ & 2 & 4 & $6(6.06)$ \\
\hline
\end{tabular}

Table-5: Persistent diarrhoea cases according age \& sex

\begin{tabular}{|c|c|c|c|c|c|c|}
\hline \multirow{2}{*}{$\begin{array}{c}\text { Persistent } \\
\text { Diarrhoea } \\
\text { organism }\end{array}$} & \multicolumn{3}{|c|}{$\begin{array}{c}\text { Age \& sex } \\
01.5-05 \text { yrs }(n-41)\end{array}$} & \multicolumn{3}{|c|}{$\begin{array}{c}\text { Age \& sex } \\
05-15 \text { yrs (n-99) }\end{array}$} \\
\hline & $\mathbf{F}$ & $\mathbf{M}$ & Total & $\mathbf{F}$ & M & Total \\
\hline Giardia & 0 & 0 & 0 & 2 & 2 & $4(4.04 \%)$ \\
\hline Kleibsella & 0 & 1 & $1(2.44 \%)$ & 1 & 1 & $2(2.02 \%)$ \\
\hline E. coli & 0 & 2 & $2(4.88 \%)$ & 1 & 0 & $1(1.01 \%)$ \\
\hline Fungus & 0 & 1 & $1(2.44 \%)$ & 0 & 2 & $2(2.02 \%)$ \\
\hline $\begin{array}{c}\text { Other associated } \\
\text { infections }\end{array}$ & 0 & 1 & $1(2.44 \%)$ & 4 & 5 & $9(9.09 \%)$ \\
\hline None & 0 & 1 & $1(2.44 \%)$ & 1 & 1 & $2(2.02 \%)$ \\
\hline Total & 0 & 06 & $06(14.63 \%))$ & 9 & 11 & $20(20.20 \%)$ \\
\hline
\end{tabular}

\section{Discussion}

Vertical transmission is the single most important cause of paediatric HIV infection. It targets CD4 expressing cells, multiplies and establishes infection. HIV escapes neutralization and immune responses due to extensive heterogenecity, produced by rapid viral replication $\left(10^{10}\right.$ particles per day) and absence of proof reading mechanism $[10,11]$. Two to four weeks after infection symptoms of acute viral syndrome appears in 50-90\% infected persons [12]. Symptoms persist for few days and difficult to differentiate from other viral infections 
[13]. High viral load at the end of acute phase (set point) is associated with poor prognosis [14,15]. Infected person may remain asymptomatic (period of latency) for variable period of time or there may be no period of latency. Destruction of CD4 cells continues, cellular and humoral immunity is severely compromised. Child becomes susceptible to variety of infections, even non pathogenic micro organisms become virulent and cause life threatening illnesses. In $30 \%$ children disease progression is very fast and they die before one year of age $[16,17]$.

Majority of perinatally infected children become symptomatic by five years of age[4]. In our study $97.96 \%$ children were infected through vertical transmission and mean age of presentation was7.67 $(\mathrm{SD} \pm 3.5)$ years. Almost similar findings have been reported by Agarwal D et al[18], Merchant RH et al[3] and Shah I[19]. In the study of Shet et al[20] mean age of presentation was $7( \pm 3.4)$ years. In our study out of 140 children, $26.43 \%$ lost their either father or mother while $7.14 \%$ lost their father and mother both and they were the worst sufferer. In the study of Foster G [21], 7 - $11 \%$ children were orphan. Failure to thrive and under nutrition is very common in these children. In our study we also noted that no child was nutritionally normal and $72.14 \%$ children had significant malnutrition.

Rakesh Lodha found $81.3 \%$ children to have failure to thrive and Ramesh $\mathrm{R}$ Pol[23] found significant malnutrition in $54.93 \%$ children. In our study maximum number $(35.7 \%)$ of children were in immunological stage I. Similar findings were reported by Agarwal D et al[18] and Shet et al [20].

Cutaneous manifestations were present in $47.14 \%$ cases in present study mainly in the form of Scabies, staphylococcal infections and PPE. Lanjewar DN, et al[9] and Panda S, et al[8] have reported cutaneous lesions in up to $90 \%$ of HIV infected individuals. Recurrent diarrhoea was seen in $18.5 \%$ cases in our study. Dinesh Kaul et al[22] reported $18 \%$ and Ramesh $\mathrm{R}$ Pol et[23] 30.9\% in their studies. Pneumocystis Jeroveci Pneumonia (PCP) was reported in one case $(0.7 \%)$ in our study. Diagnosis was made on the basis of tachypnoea, dyspnoea, tachycardia, ABG changes of hypoxemia, x-ray chest showing hyperinflation along with bilateral interstitial infiltrates and exclusion of other possible conditions. Verghese VP[24] reported it to be $8 \%$ in his study. Other reports from India have reported low rate $(0.7-7 \%)$ of PCP. This decrease may be due to increasing use of co-trimoxazole for PCP prophylaxis. In our study oropharyngeal candidiasis accounted for $7.1 \%$ cases which is comparable to Verghese VP et al report. Recurrent bacterial pneumonia including empyema in our study was seen in $11.4 \%$ children. Ramesh R Pol [23] reported it to be $12.6 \%$ and Verghese VP[24] 18\%.

In present study maximum cases of recurrent pneumonia and recurrent diarrhea were seen in age group 5-10 years. In our study $2.85 \%$ children were HBs Ag positive and one child with Anti HCV positive. Geffriaud C et al[25] have reported 29\% HBsAg positive cases in their study. According to many studies the most common OI in HIV patients is tuberculosis. Ramesh R Pol et al[23] found 38.03\% and Dhurat R et al [26] $67.5 \%$ children with tubercular infection. In our study $10 \%$ children were infected with tuberculosis. Dabla V et al [27] has reported $4.2 \%$ prevalence of pediatric tuberculosis in Delhi, in adults it is $28.07 \%$. She observed bacterial infection to be the most common OI $(36.3 \%)$ in children.

We also noted similar findings $(36.4 \%)$ in our study. Diagnosis of tuberculosis in children is often difficult due to frequently negative sputum smears, less reliable Monteux test due to under lying malnutrition and atypical radiological findings. Serious form of OI was noted in immunological stage III and IV. In 31 cases $(22.14 \%)$ more than one organisms were isolated in our study. Other studies [28,29] also have reported polymicrobial finding in advance stages of disease.

\section{Conclusion}

Spectrum of opportunistic infections are changing with time and place. Recurrent serious bacterial infections are most common OI in HIV infected children. Maximum children present around age of seven years with failure to thrive associated with anaemia. Different kinds of cutaneous involvement including scabies, papular pruritic eruptions, pyoderma, seborrhoic dermatitis, molluscum contagiosum, herpes, fungal nail infection etc are common in these children. Other 
frequent findings include oral candidiasis, recurrent diarrhoea. recurrent UTI, Parotid swelling.

If any child presents with recurrence of these symptoms with unusual severity, he or she should be investigated for HIV infection and more so if child is under nourished, father is staying away from home for longer period or there is history of unexplained untimely parental death. High suspicion index is of utmost importance to pick up early OIs to reduce morbidity and mortality.

\section{Funding: Nil, Conflict of interest: Nil \\ Permission from IRB: Yes}

\section{References}

1. Khare MD, Sharland M. Pulmonary manifestations of pediatric HIV infection. Indian J Pediatr. 1999 NovDec; 66(6):895-904.

2. Madhivanan $\mathrm{P}$, Mothi SN, Kumarasamy N, Yepthomi T, Venkatesan C, Lambert JS, Solomon S. Clinical manifestations of HIV infected children. Indian J Pediatr. 2003 Aug;70(8):615-20.

3. Merchant RH, Oswal JS, Bhagwat RV, Karkare J. Clinical profile of HIV infection. Indian Pediatr. 2001 Mar; 38(3):239-46.

4. Kumarasamy N, Solomon S, Flanigan TP, Hemalatha R, Thyagarajan SP, Mayer KH. Natural history of human immunodeficiency virus disease in southern India. Clin Infect Dis. 2003 Jan 1;36(1):79-85. Epub 2002 Dec 9.

5. Singh A, Bairy I, Shivananda PG. Spectrum of opportunistic infections in AIDS cases. Indian $\mathrm{J}$ Med Sci. 2003 Jan;57(1):16-21.

6. Misra SN, Sengupta D, Satpathy SK. AIDS in India: Recent trends in opportunistic infections. The Southeast Asian J Trop Med Public Health 1998 Jun; 29 (2) : 373-76.

7. Kumar P, Sharma N, Sharma NC, Patnaik S. Clinical profile of tuberculosis in patients with HIV infection/AIDS. Indian J Chest Dis Allied Sci 2002; 44:159-63.

8. Panda S, Sarkar S, Mandal BK, Singh TB, Singh KL, Mitra DK, et al. Epidemic of herpes zoster following
HIV epidemic in Manipur, India. J Infect 1994; 28: 167-73.

9. Lanjewar DN, Bhosale A, Iyer A. Spectrum of dermatopathologic lesions associated with HIV/AIDS in India. Indian J Pathol Micribiol 2002; 45(3): 293-98.

10. Mc Cutchan FE. Understanding the genetic diversity of HIV-1. AIDS 2000; 14 suppl 3: S31-44.

11. Peeters M, Sharp PM. Genetic diversity of HIV-1: the moving target. AIDS 2000; 14 suppl: S129-40.

12.Daar ES, Little S, Pitt J, Santangelo J, Pauline Ho, Harawa N, et al. Diagnosis of primary HIV-1 infection. Ann Intern Med 2001; 134(1): 25-29.

13. Schacker T, Collier AC, Hughes J, Shea T, Corey L. Clinical and epidemiological features of primary HIV infection. Ann Intern Med 1996; 125(4): 257-64.

14. Mellors JW, Kingsley LA, Rinaldo CR, Todd JA, Hoo BS, Kokka RP, et al. Quantification of HIV-1 RNA in plasma predicts outcome after seroconversion. Ann Intern Med 1995; 122(8): 573-79.

15. Vergis EN, Mellors JW. Natural history of HIV-1 infection. Infect Dis Clin North Am 2000 Dec; 14(4): 809-25.

16. Newell ML, Coovadia H, Cortina-Borja M, Rollins N, Gaillard P, Dabis F. Mortality of infected and uninfected infant born to HIV infected mothers in Africa: a pooled analysis. Lancet 2004 Oct2-8; 364(9441): 1236-43.

17. aha TE, Dallabetta GA, Canner JK. The effect of human immunodeficiency virus infection on birth weight and infant and child mortality in urban Malawi. Int J Epidemiol 1995; 24(5): 1022-29.

18. Agarwal D, Chakravarty J, Sunder S, Gupta V, Bhatia BD. Co-relation between clinical features and degree of immunosuppression in HIV infected children. Indian Pediatr 2008 Feb; 45(2): 140-43.

19. Shah I. Age related clinical manifestations of HIV infection in Indian children. J Trop Pediatr. 2005 Oct; 51(5):300-3. Epub 2005 Jun 24.

20. Shet A, Mehta S, Rajagopalan N, Dinakar C, Ramesh E, Samuel NM, Indumathi CK, Fawzi WW, 
Kurpad AV. Anemia and growth failure among HIVinfected children in India: a retrospective analysis. BMC Pediatr. 2009 Jun 16;9:37. doi: 10.1186/14712431-9-37.

21. Foster G. Supporting community efforts to assist orphans in Africa. N Engl J Med 2002 July; 346(24): 1907-10.

22. Kaul D, Patel JA. Clinical manifestations and management of pediatric HIV infection. Indian J Pediatr. 2001 Jul;68(7):623-31.

23. Pol RR, Shepur TA, Ratageri VH. Clinicolaboratory profile of pediatric HIV in Karnataka. Indian J Pediatr. 2007 Dec;74(12):1071-5.

24. Verghese VP, Cherian T, Cherian AJ, Babu PG, John TJ, Kirubakaran C,et al. Clinical manifestation of HIV-I infection. Indian Pediatr 2002 Jan; 39(1): 57-63.

25. Geffriaud C, Poynard T, Delfraissy JF, Bedossa P, Naveau S, Bourée P, Dubreuil P, Chaput JC. [Hepatic involvement in HIV 1 virus infection]. Gastroenterol Clin Biol. 1988 May;12(5):465-72.

26. Dhurat R, Manglani M, Sharma R, Shah NK. Clinical spectrum of HIV infection. Indian Pediatr. 2000 Aug;37(8):831-6.

27. Dabla V, Gupta AK, Singh I. Spectrum of opportunistic infections among HIV seropositive patients in Delhi region- a study by Delhi state AIDS control society. Journal of Medical Disorders 2015http://dx.doi.org/10.7243/2053-3659-3-1

28. Shailaja VV, Pai LA, Mathur DR, Lakshmi V. Prevalence of bacterial and fungal agents causing lower respiratory tract infection in patients with human immunodeficiency virus infection. Indian $\mathrm{J}$ Med Microbiol 2004; 22: 28-33.

29. Banerjee U. Progress in diagnosis of opportunistic infections in HIV/AIDS. Indian J Med Res 2005 Apr; 121: 395-406.

\section{How to cite this article?}

Pandey C.M, Shrivastava A. Spectrum of opportunistic infections in HIV infected children in North India. Int. J Pediatr Res.2016;3(10):731-737.doi:10.17511/ijpr.2016.i10.03 